\title{
Incidence of Hypertension in a Cohort of Spanish University Graduates: The SUN Study
}

\author{
Juan J. Beunza, ${ }^{\mathrm{a}, \mathrm{b}}$ Miguel Á. Martínez-González, ${ }^{a}$ Manuel Serrano-Martínez, ${ }^{\mathrm{a}, \mathrm{c}}$ and Álvaro Alonso ${ }^{\mathrm{a}, \mathrm{d}}$
}

aDepartamento de Medicina Preventiva y Salud Pública, Universidad de Navarra, Clínica Universitaria,

Pamplona, Navarra, Spain

bDepartamento de Medicina Interna, Universidad de Navarra, Clínica Universitaria, Pamplona,

Navarra, Spain

'Servicio de Atención Primaria, Servicio Navarro de Salud, Pamplona, Navarra, Spain

dDepartment of Epidemiology, Harvard School of Public Health, Boston, MA, USA

Hypertension is a major public health problem. However, no estimates of age- and sex-specific incidences are available for the Spanish population. Our objective was to estimate the incidence of hypertension in a cohort of university graduates in Spain. We followed up 5648 individuals aged 25-65 years who were initially free of hypertension, diabetes, and cardiovascular disease for a median of 30 months. New diagnoses of hypertension were identified using mailed questionnaires. We validated the self-reported diagnosis of hypertension. In 18250 person-years of follow-up, we identified 248 new cases of hypertension. The unadjusted incidences of hypertension in women and men were $8.2 \mathrm{per}$ 1000 person-years $(95 \% \mathrm{Cl}, 6.7-10.1)$ and 21.8 per 1000 person-years $(95 \% \mathrm{Cl}, 18.6-25.4)$, respectively. The cumulative probability of receiving a medical diagnosis of hypertension by the age of 65 years was $50 \%$ among women and $72 \%$ among men. In conclusion, we have provided new evidence confirming that hypertension is one of the most important public health problems in Spain.

Key words: Hypertension. Incidence. Prospective studies. Spain.

\section{Incidencia de hipertensión arterial en una cohorte de graduados universitarios españoles: el estudio SUN}

La hipertensión arterial (HTA) es un importante problema de salud pública. Sin embargo, no hay estimaciones en España de su incidencia específica por edad y sexo. Nuestro objetivo fue estimar la incidencia de HTA en una cohorte de universitarios. Se incluyó a 5.648 individuos de 25-65 años de edad inicialmente libres de HTA, diabetes y enfermedad cardiovascular, a los que se siguió durante 30 meses. Se determinaron los nuevos diagnósticos de HTA mediante cuestionarios. Se validaron los diagnósticos autorreferidos de HTA. De 18.250 personasaño de seguimiento identificamos 248 nuevos casos de HTA. La incidencia bruta en mujeres (edad media, 33 años) y varones (edad media, 38 años) fue, respectivamente, 8,2 (intervalo de confianza [IC] del 95\%, 6,7-10,1) y 21,8 (IC del 95\%, 18,6-25,4) por 1.000 personas-año. La probabilidad acumulada de recibir un diagnóstico médico de HTA a los 65 años fue del $50 \%$ en mujeres y del $70 \%$ en varones.

Palabras clave: Hipertensión arterial. Incidencia. Estudios prospectivos. España.
The SUN Study has been funded by the FIS - Spanish Ministry of Health (Grants PI030678, PI040233, and G03/140), the Navarra Regional Government (Grant PI41/2005) and the University of Navarra. Dr Álvaro Alonso was supported by a Fulbright fellowship.

Correspondence: Dr. Álvaro Alonso,

Department of Epidemiology. Harvard School of Public Health,

677 Huntington Avenue. Boston. 02115 MA, USA,

E-mail: aalogut@alumni.unav.es

Received July 26, 2005.

Accepted for publication March 23, 2006.

\section{INTRODUCTION}

Despite the importance of hypertension (HT) as a public health problem (high prevalence, impact on morbimortality), ${ }^{1-3}$ there are no estimates reporting ageand sex-specific incidence rates of HT in Spain. To our knowledge, only the DRECE II Study reported the crude cumulative incidence and the incidence rate of HT in a population followed prospectively, but the authors did not provide specific incidences for different age and sex strata. $^{4}$

Our objective was to describe the incidence rate of HT according to age and sex in a prospective cohort, the 
Seguimiento Universidad de Navarra (SUN, University of Navarra Follow-up) Study.

\section{METHODS}

\section{Study Participants}

The SUN study is a dynamic cohort of university graduates, designed to study the association between dietary factors and hypertension, obesity, and cardiovascular disease. Its methods have been described with detail elsewhere. ${ }^{5}$ Briefly, beginning in December 1999, an invitation letter and a questionnaire were sent to all graduates from the University of Navarra, and members of some other professional associations. The questionnaire gathered information on sociodemographic variables, lifestyle factors (smoking, physical activity, diet), and clinical data (personal and family history of several conditions). From December 1999 to December 2002, 11555 individuals answered the questionnaire. Subsequently, the follow-up of initial responders was made through biennial mailed questionnaires, with up to five mailings to those who did not reply. In December 31, 2005, 9695 had answered the 2-year and 5150 the 4-year follow-up questionnaire. Overall, the follow-up proportion was $85 \%$. The age range of participants was 20 to 90 years old at baseline. For this analysis, we included only participants in the age range 25-65, and we excluded individuals reporting at baseline a history of cardiovascular disease, cancer or diabetes, those with prevalent HT, and those with extreme caloric intakes or missing values for age, sex, diet, body mass index or physical activity. Finally, 5648 persons were included in the study. The average age was 33 years for women and 38 for men. The Institutional Review Board of the University of Navarra approved the study protocol.

\section{Hypertension Ascertainment}

In both the baseline and follow-up questionnaires, we asked participants whether they have received a medical diagnosis of HT. Additionally, the baseline questionnaire inquired for the most recent systolic and diastolic BP. The follow-up questionnaire also requested the date of HT diagnosis.

A participant was considered to have $\mathrm{HT}$ at baseline if she or he reported a medical diagnosis of HT, was taking antihypertensive medication or reported a systolic $\mathrm{BP} \geq 140 \mathrm{~mm} \mathrm{Hg}$ and/or a diastolic $\mathrm{BP} \geq 90 \mathrm{~mm} \mathrm{Hg} .{ }^{6} \mathrm{New}$ cases of HT were defined as those individuals reporting a physician-diagnosis of HT in the follow-up questionnaire and did not have HT at baseline.

A validation study was conducted in a random sample of participants $(n=127)$ in the metropolitan area of Pamplona (Navarra, Spain). It showed an adequate validity of the self-reported diagnosis of HT in this highly educated cohort (positive predictive value: $82 \%$, and negative predictive value $85 \%$ ) when a directly measured value of BP (repeated twice) was used as the gold standard.

\section{Statistical Analysis}

For each participant, we computed person-time of follow-up from the date of return of the baseline questionnaire to the date of return of the last follow-up questionnaire, or the date of diagnosis of HT for new cases of the disease. Age and sex-specific incidence rates of HT were computed as the number of new cases of HT divided by the person-time of follow-up in each age-sex group, and were summarized by calculating the corresponding cumulative probability of having a diagnosis of HT by age $65 .{ }^{8}$

\section{RESULTS}

From the 11555 initial responders, we excluded 3538 participants because of the presence of one or more of the exclusion criteria. That left 8017 participants available for the analysis. From them, 6776 answered the 2-year and 3659 answered also the 4-year follow-up questionnaire. The median follow-up was 30 months. This represents a follow-up of 20031 person-years (study base), 18250 person-years of the study base corresponded to participants aged 25-65 years. Baseline characteristics of women and men that responded the follow-up questionnaire are shown in Table 1. Women in our population were younger, leaner, less active, and had an overall healthier dietary pattern than men.

Among women, 91 new cases of HT were identified, and 157 among men. The crude incidence rate of HT (95\% confidence intervals) was $8.2(6.7-10.1)$ per 1000 person-years of follow-up in women and 21.8 (18.6-25.4) in men. Age- and sex-specific incidences rates, and their

\section{TABLE 1. Description of the Cohort (Separately for} Men and Women)

\begin{tabular}{lcc}
\hline & Women & Men \\
\hline No. & 4164 & 2631 \\
Age, y & $33.3(9.4)$ & $38.2(11.2)$ \\
Body mass index, kg/m² & $21.8(2.8)$ & $25.0(2.9)$ \\
$\begin{array}{l}\text { Physical activity } \\
\quad \text { METs-hours/week) }\end{array}$ & $22.0(23.4)$ & $30.3(29.4)$ \\
Alcohol intake, g/d & $3.8(5.8)$ & $9.7(11.7)$ \\
Sodium intake, g/d & $3.5(2.1)$ & $4.2(2.6)$ \\
Low-fat dairy consumption, g/d & $238.4(253.7)$ & $149.7(216.5)$ \\
Vegetable consumption, g/d & $539.2(313.3)$ & $454.6(324.1)$ \\
Fruit consumption, g/d & $341.7(291.9)$ & $284.3(269.1)$ \\
\hline
\end{tabular}

Values are means (standard deviation) 
TABLE 2. Incidence of Hypertension in the SUN Cohort (1999-2004)

\begin{tabular}{|c|c|c|c|c|c|c|c|c|}
\hline \multirow[b]{2}{*}{ Age Group } & \multicolumn{4}{|c|}{ Women } & \multicolumn{4}{|c|}{ Men } \\
\hline & $\begin{array}{c}\text { Cases } \\
\text { of } \\
\text { Hypertension }\end{array}$ & Person-Years & $\begin{array}{c}\text { Incidence } \\
\text { (Cases per } 1000 \\
\text { Persons-Year) }\end{array}$ & $\begin{array}{c}95 \% \\
\text { Confidence } \\
\text { Interval }\end{array}$ & $\begin{array}{c}\text { Cases } \\
\text { of Hypertension }\end{array}$ & Person-Years & $\begin{array}{c}\text { Incidence } \\
\text { (Cases per } 1000 \\
\text { Persons-Year) }\end{array}$ & $\begin{array}{c}95 \% \\
\text { Confidence } \\
\text { Interval }\end{array}$ \\
\hline $25-34$ & 28 & 6044.8 & 4.6 & $3.1-6.6$ & 24 & 2769.9 & 8.7 & 5.7-12.7 \\
\hline $35-44$ & 29 & 3182.8 & 9.1 & $6.2-12.9$ & 54 & 2393.7 & 22.6 & $17.9-28.1$ \\
\hline $45-54$ & 17 & 1439.2 & 11.8 & 7.1-18.5 & 49 & 1490.0 & 32.9 & $24.6-43.1$ \\
\hline $55-64$ & 17 & 390.5 & 43.5 & 26.3-68.1 & 30 & 539.4 & 55.6 & $38.3-78.3$ \\
\hline Total & 91 & 11057.3 & 8.2 & 6.7-10.1 & 157 & 7193.0 & 21.8 & $18.6-25.4$ \\
\hline
\end{tabular}

95\% confidence intervals, are shown in Table 2 . The incidence rate of HT significantly increased with age, and it was higher for men than for women across all age categories $(P<.05)$.

Under usual assumptions, including the supposition of no competing risks, ${ }^{8}$ the cumulative probability of being medically diagnosed of hypertension by age 65 in this cohort was $50 \%$ in women and $70 \%$ in men.

\section{DISCUSSION}

In this study, we report for the first time age and sex-specific incidence rates of HT in a large Spanish cohort. Interestingly, we show a very high cumulative incidence of a diagnosis of HT before age 65, particularly among men. The observed cumulative incidences were similar to prevalence estimates for HT among European population older than $65 .{ }^{9}$ In Spain, only the DRECE II Study reported incidence rates of HT, but the authors did not report specific incidences for different age and sex groups. ${ }^{4}$ Other cohort studies have provided comparable age and sexspecific incidences of HT. ${ }^{10-12}$

Our study has several methodological limitations. First, the diagnosis of HT is based in self-reported data. We have shown, however, the adequate validity of selfreported HT diagnosis. ${ }^{7}$ Nonetheless, the observed incidence of HT in this population most likely underestimates the true incidence of HT, due to the relatively high proportion of undiagnosed cases of HT among the general population. The high educational level of all members of the cohort probably reduced the impact of underreporting.

Another potential limitation is the potential lack of generalizability of our results to the Spanish population. The participants in the SUN Study are all of them university graduates, and most likely they follow healthier lifestyles, implying that the reported rates of HT are probably lower that the incidence rates in the general Spanish population. Our aim, however, is not to provide accurate data on the incidence of HT in Spain, but to add new information to the epidemiology of HT beyond that derived from prevalence data.

\section{CONCLUSSIONS}

In conclusion, in the absence of estimates of incidence rates based on representative nation-wide surveys obtained using direct measurements, our data shows that the incidence of HT was relatively high in a defined Spanish population, especially among men. This was more evident when we considered the cumulative incidence of a HT diagnosis by age 65 . Studies conducted in the general population, using direct measurement of BP, would allow a better definition of the problem.

\section{ACKNOWLEDGMENTS}

We thank the collaboration of all the SUN Study participants, and Dr Javier Díez for his comments in an early version of this manuscript.

\section{REFERENCES}

1. Banegas JR, Rodríguez-Artalejo F. El problema de la hipertensión arterial en España. Rev Clin Esp. 2002;202:12-5.

2. Llisterri Caro JL, Rodríguez Roca GC, Alonso Moreno FJ, Lou Arnal S, Divisón Garrote JA, Santos Rodríguez JA, et al. Control de la presión arterial en la población hipertensa española atendida en atención primaria. Estudio PRESCAP 2002. Med Clin (Barc). 2004;122:165-71.

3. Banegas JR, Rodríguez-Artalejo F, de la Cruz Troca JJ, de Andrés Manzano B, del Rey Calero J. Mortalidad relacionada con la hipertensión y la presión arterial en España. Med Clin (Barc). 1999;112:489-94.

4. Gutiérrez Fuentes JA, Gómez-Gerique J, Gómez de la Camara A, Rubio MA, García Hernández A, Arístegui I. Dieta y riesgo cardiovascular en España (DRECE II). Descripción de la evolución del perfil cardiovascular. Med Clin (Barc). 2000;115: 726-9.

5. Martínez-González MA. The SUN cohort study (Seguimiento University of Navarra). Public Health Nutr 2006;(en prensa).

6. Chobanian AV, Bakris GL, Black HR, Cushman WC, Geen LA, Izzo JL Jr, et al. The Seventh Report of the Joint National Committee on Prevention, Detection, Evaluation, and Treatment of High Blood Pressure: The JNC 7 Report. JAMA. 2003;289:2560-71.

7. Alonso A, Beunza JJ, Delgado-Rodríguez M, Martínez-González MA. Validation of self reported diagnosis of hypertension in a cohort of university graduates in Spain. BMC Public Health. 2005;5:94.

8. Rothman KJ, Greenland S. Measures of disease frequency. En: Rothman KJ, Greenland S, editors. Modern Epidemiology. 2nd ed. Philadelphia: Lippincott Williams \& Wilkins; 1998. p. 29-46. 
9. Wolf-Maier K, Cooper RS, Banegas JR, Giampaoli S, Hense HW, Joffres J, et al. Hypertension prevalence and blood pressure levels in 6 European countries, Canada, and the United States. JAMA. 2003;289:2363-9.

10. Ascherio A, Rimm EB, Giovanucci EL, Colditz GA, Rosner B, Willett WC, et al. A prospective study of nutritional factors and hypertension among US men. Circulation. 1992;86:1475-84.
11. Ascherio A, Hennekens CH, Willett WC, Sacks FM, Rosner B, Manson JE, et al. Prospective study of nutritional factors, blood pressure, and hypertension among US women. Hypertension. 1996;27:1065-72.

12. Dannenberg AL, Garrison RJ, Kannel WB. Incidence of hypertension in the Framingham Study. Am J Public Health. 1988;78:676-9. 